\title{
RESPONS PETANI TERHADAP PENGGUNAAN PUPUK BOKHASI FESES AYAM DI SINDUAGUNG WONOSOBO
}

(Farmers Response Towards The Using Of Chicken Feces As Bokashi Fertilizer At Sinduagung Village Wonosobo Regency)

\section{Teguh Susilo}

\author{
email: teguhstpp@yahoo.co.id \\ ${ }^{1}$ Staf Pengajar Sekolah Tinggi Penyuluhan Pertanian Magelang \\ Jl. Magelang-Kopeng Km7 Purwosari Tegalrejo Magelang PO BOX 150
}

Diterima: 13 September 2014 Disetujui: 30 Juni 2015

\begin{abstract}
This research was done on May $5^{\text {th }}$ until July $4^{\text {th }} 2014$ at Sinduagung Village Selomerto District Wonosobo Regency Central Java Province. The purpose to be achived is to know farmers response and to know the factors that influence the farmers response towards using of chicken feces as a bokashi fertilizer.The equipments that are used on the counseling such as LCD, laptop, stationery and also skill elements to give them a demo in how to make a bokashi fertilizer. It used to make bokashi fertilizer are scales, bucket, termometer, gloves and tarpaulin. Then the materials needed in the process are chicken feces, bran, husk, molase (granulated sugar), EM4 and water.Researchon Sinduagung Village Selomerto District Wonosobo Regency giving some results on the farmers response towards the using of chicken feces as a bokashi fertilizer by increasing the knowladge aspects by 11 points from the don't know to become understand categories, then the manner aspects are 6,1 points from less agree to be become agree, the skill aspects are 10,322 from unskilled to become skilled. Then the results from the counseling shows amounts of EP by 84,38 \% and EPP by 71,942\%. The result from multiple linier analysis shows that farmers aspects contribute a very significant effect towards the farmers response and the raising livestock experience from the farmers contribute a significant effect towards farmers response, whilst education and the amount of livestock ownership do not have a sigificant effect towards farmerrs' response in using chicken feces as bokashi fertilizer.
\end{abstract}

Keyword: Response, chicken feces, bokashi

\begin{abstract}
ABSTRAK
Penelitian dilaksanakan pada tanggal5 Mei 2014 sampai dengan 4 Juli 2014 di Desa Sinduagung Kecamatan Selomerto Kabupaten Wonosobo Propinsi Jawa Tengah. Tujuan yang ingin dicapai adalah untuk mengetahui respons petani serta mengetahui faktor-faktor yang mempengaruhi respons petani terhadap pemanfaatan feses ayam sebagai pupuk bokashi.Alat yang digunakan dalam penyuluhan berupa folder, LCD, Laptop, alat tulis lengkap, dan elemen keterampilan untuk memandu dalam pelaksanaan demonstrasi cara pembuatan pupuk bokashi. Sedangkan alat yang digunakan untuk pembuatan pupuk bokashi yaitu timbangan, ember, termometer, sarung tangan, terpal.Bahan yang digunakan
\end{abstract}


untuk pembuatan pupuk bokashi yaitu feses ayam, dedak, sekam, molase (gula pasir), EM4 dan air. Hasil penelitian di Desa Sinduagung Kecamatan Selomerto Kabupaten Wonosoboyaitu responpetani terhadap pemanfaatan feses ayam sebagai pupuk bokashi mengalami peningkatan pada aspek pengetahuan dengan nilai 11 dari kategori tidak tahu menjadi tahu, aspek sikap 6,1 dari kurang setuju menjadi setuju, aspek keterampilan 10,322 dari tidak terampil menjadi terampil. Hasil penyuluhan menunjukkan EP sebesar 84,38\% dan EPP 71,942\%. Hasil anilisis linier berganda menunjukkan bahwa umur petani berpengaruh sangat signifikan terhadap respons petani dan pengalaman beternak berpengaruh signifikan terhadap respons petani sedangkan pendidikan dan jumlah kepemilikan ternak tidak berpengaruh signifikan terhadap respons petani dalam memanfaatkan feses ayam sebagai pupuk bokashi

Kata Kunci: Respon, feses ayam, bokashi

\section{PENDAHULUAN}

\section{Latar Belakang}

Beternak tidak bisa dipisahkan dari kehidupan masyarakat Indonesia yang ada di pedesaan. Mereka beternak dengan tujuan sekedar memanfaatkan lahan atau sebagai usaha untuk memenuhi kebutuhan gizi keluarga. Beternak ayam termasuk salah satu komoditas yang digemari. Dalam beternak ayam tidak terlepas dari limbah kotoran yang dihasilkan. Kotoran/feses ayam jika dibiarkan saja menjadi permasalahan tersendiri karena di rasa mengganggu kebersihan lingkungan.

Feses merupakan salah satu hasil sampingan dari peternakan ayam yang terkadang masih dikesampingkan. Untuk menjaga agar feses ayam dan sisa-sisa pakan tidak mencemari lingkungan, pengelolaan limbah peternakan ayam dengan baik juga akan memberikan nilai manfaat.Limbah kotoran ayam dapat dimanfaatkan sebagai pupuk bokashi. Pupuk bokashi adalah pupuk yang berasal dari bahan organik, dimana bahan organik merupakan senyawa penting penyusun tanah. Menurut Lingga (1995), bokashi kotoran ayam yang diberikan mengandung EM4 dapat memfermentasikan bahan organik sehingga menghasilkan senyawa yang dapat diserap langsung oleh akar tanaman.

Desa Sinduagung memiliki dua dusun

yaitu Dusun Kresek dan Dusun Keseneng.Tedapat dua Kelompok Tani dan satu Kelompok Wanita Tani. Kegiatan Kelompok Wanita Tani sejak tahun 2013 yaitu mewujudkan kawasan rumah pangan lestari dengan memanfaatkan pekarangan untuk ditanami sayuran, disamping itu juga mengembangkan ternak ayam sebagai pemenuhan sumber gizi keluarga. Untuk mewujudkan konsumsi pangan keluarga yang bergizi, sehat dan aman maka pelaksanaan bertanam sayuran ini diupayakan menggunakan pupuk organik.

Melihat masalah limbah kotoran ayam dihasilkan pada ternak ayam tersebut, sejalan dengan keinginan bertanam organik maka penulis mencoba memperkenalkan anggota kelompok agar dapat memanfaatkan hasil kotoran ayam tersebut untuk di buat sebagaibokashi.

Hal ini yang menjadi dasar penelitian dengan judul "Respons PetaniTerhadap Pemanfaatan Feses Ayam Sebagai Pupuk Bokashi di Desa Sinduagung Kabupaten Wonosobo" 
Masalah

Berdasarkan hasil identifikasi ditemukan permasalahan yaitu:

1. Belum diketahui respons (pengetahuan, sikap, keterampilan) petani terhadap pemanfaatan feses ayam sebagai pupuk bokashi.

2. Belum diketahui faktor - faktor yang mempengaruhi respons petani terhadap pemanfaatan feses ayam sebagai pupuk bokashi.

\section{Tujuan}

Tujuan yang ingin dicapai dengan melihat permasalahan yang ada adalah:

1. Untuk mengetahui sejauh mana respons (pengetahuan, sikap, keterampilan) petani terhadap pemanfaatan feses ayam sebagai pupuk bokashi.

2. Untuk mengetahui faktor- faktor yang mempengaruhi respons petani terhadap pemanfaatan feses ayam sebagai pupuk bokashi.

\section{MATERI DAN METODE}

\section{Materi}

\section{Alat dan Bahan}

Alat bantu yang digunakan untuk kegiatan penyuluhan adalah 1) Daftar Pertanyaan (Kuesioner), untuk membantu dalam pengumpulan data primer, 2) Alat tulis menulis digunakan untuk mencatat hasil wawancara dengan responden, 3) Media alat bantu dalam penyuluhan adalah 1 unit laptop, LCD (Liquid Crystal Display) dan folder. 4) Metode penyuluhan dengan demonstrasi cara. Alat yang digunakan untuk demonstrasi cara adalah: Karung/terpal, cangkul, sarung tangan, ember, termometer. Bahan yang digunakan untuk demonstrasi cara adalah: feses ayam, molase (larutan gula), bio activator (EM4), air.

\section{Lokasi dan Waktu}

Pelaksanaan penelitian mulai tanggal 5 Mei 2014 sampai 4 Juli 2014. Lokasi pelaksanaan di Kelompok Wanita Tani Subur Makmur di Desa Sinduagung, Kecamatan Selomerto Kabupaten Wonosobo.

\section{Jalannya Pengkajian}

\section{Metode pengambilan sampel}

Metode pengambilan sampel yang digunakan didalam pengkajian ini adalah purposive sampling. Zuriah (2006), mengatakan bahwa pemilihan sekelompok subjek dalam purposive sampling didasarkan atas ciri-ciri tertentu yang dipandang mempunyai sangkut paut yang erat dengan populasi yang diketahui sebelumnya. Dengan kata lain unit sampel yang dihubungi sesuai dengan kriteria kriteria tertentu. Sementara menurut Arikunto (2002), purposive sampling dilakukan dengam cara mengambil subjek bukan didasarkan atas strata, random atau daerah tetapi didasarkan atas adanya tujuan tertentu. Pengambilan sampel harus didasarkan atas ciri, sifat, atau karakteristik tertentu yang merupakan ciri pokok populasi.

Adapun kriteria yang akan diambil sebagai sampel adalah sebagai berikut: 1). Petani - ternak yang memelihara ayam, 2). Petani yang tergabung dalam Kelompok Wanita Tani Subur Makmur Desa Sinduagung.

Sampel yang diambil dalam pengkajian ini berjumlah 30 orang. Menurut Soehartono (1998), sampel yang diambil dalam aspek sosial adalah 
responden sebanyak 30 orang. Hal ini disampaikan juga oleh Sekaran (2006) dalam Hendri (2010) bahwa secara umum untuk penelitian korelasional jumlah sampel minimal untuk memperoleh hasil yang baik adalah 30 orang. Dijelaskan lebih lanjut bahwa ukuran sampel lebih dari 30 dan kurang dari 150 adalah tepat untuk kebanyakan penelitian.

\section{Cara pengumpulan data}

Data primer, yaitu data yang diperoleh secara langsung dari petani responden dengan cara wawancara menggunakan kuesioner. Data primer dalam pengkajian ini adalah data perubahan perilaku meliputi pengetahuan, sikap dan keterampilan petani.

Data sekunder, yaitu data yang diperoleh dari sumber yang berkaitan dengan masalah yang akan diteliti. Data sekunder diambil dari data yang ada di instansi terkait. Data sekunder dalam pengkajian ini adalah data monografi desa. Data yang diperlukan dikumpulkan dengan menggunakan: Wawancara. Dokumentasi dan pencatatan.

\section{Rancangan pengkajian}

Rancangan pengkajian dilakukan dengan pengukuran respons sebelum dan setelah dilakukan penyuluhan untuk mengetahui sejauh mana tingkat pengetahuan, sikap dan keterampilan petani terhadap pemanfaatan feses ayam sebagai pupuk bokashi. Responden diambil 30 orang dengan melakukan wawancara langsung mengenai pemanfaatan feses ayam sebagai pupuk bokashi menggunakan alat bantu kuesioner (yang menunjukkan tingkatan atau jenjang setiap gejala diukur dengan menggunakan skala likert.

Skala likert digunakan untuk mengukur sikap, pendapat dan persepsi seseorang tentang kejadian atau gejala sosial (Riduwan, 2010). Skala likert yang digunakan yaitu: Respons tinggi (5), Respons sedang (3) Respons rendah (1), dimana daftar pertanyaan merupakan alternatif pengungkapan permasalahan yang didasarkan pada variabel yang diamati yaitu perubahan perilaku yang terdiri dari tiga aspek, yaitu aspek pengetahuan, sikap dan keterampilan.

Rancangan pengkajian yang digunakan adalah rancangan yang bersifat Deskriptif, yaitu pengkajian yang diarahkan untuk memberikan gejala - gejala, fakta fakta, kejadian - kejadian secara sistematis dan akurat mengenai sifat-sifat populasi atau daerah tertentu (Zuriah, 2006).

Dalam rancangan ini, pengamatan dan pengukuran di lakukan sebelum dan sesudah variabel bebas atau perlakuan di kenakan pada satu kelompok subjek yang diteliti (O1 - T - O2) dengan penjelasan, $\mathrm{O} 1$ = pengukuran sebelum kelompok subjek memperoleh perlakuan, $\mathrm{T}=$ perlakuan berupa penyuluhan kepada responden yang sama, $\mathrm{O} 2$ = pengukuran sesudah kelompok subjek memperoleh perlakuan. Perbedaan hasil pra test dan post test merupakan perubahan dampak dari kegiatan penyuluhan.

\section{Pelaksanaan pengkajian}

Kegiatan penelitian dilaksanakan pada bulan Mei-Juli 2014. Untuk mengawali kegiatan, tiba di lokasi melapor kepada Koordinator BPP Kecamatan Selomerto, selanjutnya koordinasi dengan pengurus kelompok untuk sosialisasi kegiatan-kegiatan yang akan dilaksanakan.

\section{Variabel Pengkajian}

Variabel yang akan diamati dalam pengkajian ini yaitu: 
a. Perubahan perilaku mencakup pengetahuan, sikap dan keterampilan.

b. Faktor- faktor yang mempengaruhi respons petani yaitu:

Umur peternak, Pendidikan peternak, Pengalaman beternak; Jumlah kepemilikan ternak.

\section{Analisis Data}

Dalam rancangan ini, pengamatan dan pengukuran dilakukan sebelum dan sesudah variabel bebas atau perlakuan dikenakan pada satu kelompok subjek yang diteliti $(\mathrm{O} 1-\mathrm{T}-\mathrm{O} 2)$ dengan penjelasan sebagai berikut:

$$
\begin{aligned}
\mathrm{O} 1= & \begin{array}{l}
\text { pengukuran sebelum kelompok } \\
\text { subjek memperoleh perlakuan }
\end{array} \\
\mathrm{T}= & \begin{array}{l}
\text { Perlakuan }(\text { Treatment }) \text {, berupa } \\
\text { penyuluhan kepada responden }
\end{array} \\
\mathrm{O} 2= & \begin{array}{l}
\text { yang sama } \\
\text { pengukuran sesudah kelompok }
\end{array} \\
& \begin{array}{l}
\text { subjek memperoleh perlakuan. } \\
\text { dampak dari kegiatan } \\
\text { penyuluhan. }
\end{array}
\end{aligned}
$$

Perbedaaan hasil pra test dan post test merupakan perubahan dampak dari kegiatan penyuluhan. Berdasarkan hasil pra test dan post test ditentukan kategori penilaian menggunakan skala likert yaitu jumlah skor maksimal dari pertanyaan variabel ukur dikurangi jumlah skor minimal kemudian selisihnya dibagi tiga. Jumlah pertanyaan pada masing-masing tingkat perubahan perilaku ada lima.

Untuk mengetahui faktor - faktor yang mempengaruhi respons petani tentang pemanfaatan feses ayam sebagai bokashi dengan menggunakan model analisis regresi linear berganda. Syarat sebuah analisis regresi linear dapat digunakan adalah dengan terpenuhinya uji asumsi klasik, maka model regresi yang akan digunakan adalah:

$Y=a+b_{1} X_{1}+b_{2} X_{2}+b_{3} X_{3}+b_{4} X_{4}+e$

$\mathrm{Y}=$ Respon

$\mathrm{X}_{1}=$ Pendidikan peternak (Tahun)

$\mathrm{X}_{2}=$ Umur peternak (Tahun)

$\mathrm{X}_{3}=$ Pengalaman beternak (Tahun)

$\mathrm{X}_{4}=$ Jumlah kepemilikan ternak ayam (Tahun)

$\mathrm{a}=$ Konstanta

$b_{1}=$ Koefisiensi regresi persial yang menghubungkan pendidikan peternak terhadap pemanfaatan feses ayam sebagai bokashi

$\mathrm{b}_{2}=$ Koefisiensi regresi persial yang menghubungkan umur peternak terhadap pemanfaatan feses ayam sebagai bokashi

$\mathrm{b}_{3}=$ Koefisiensi regresi persial yang menghubungkan pengalaman peternak terhadap pemanfaatan feses ayam sebagai bokashi

$\mathrm{b}_{4}=$ Koefisiensi regresi persial yang menghubungkan jumlah kepemilikan ternak terhadap pemanfaatan feses ayam sebagai bokashi.

$\mathrm{e}=$ faktor lain diluar persamaan.

\section{HASIL DAN PEMBAHASAN}

\section{Perubahan Perilaku}

\section{Aspek pengetahuan}

Hasil dari analisis pra test dan post test pada aspek pengetahuan responden menunjukan data seperti terlihat pada Tabel 1. 
Tabel 1. Hasil Penilaian pada Aspek Pengetahuan

\begin{tabular}{lccc}
\hline \multirow{2}{*}{ Variabel pertanyaan } & \multicolumn{2}{c}{ Nilai rata - rata } & \multirow{2}{*}{ Selisih } \\
\cline { 2 - 3 } & Pra test & Post test & \\
\hline Manfaat kotoran ayam & 3,133 & 4,933 & 1,800 \\
Pengertian bokashi & 1,867 & 4,200 & 2,330 \\
Manfaat bokashi & 1,733 & 4,133 & 2,400 \\
Fungsi EM4 & 1,400 & 3,533 & 2,133 \\
Cara membuat bokashi & 1,533 & 3,867 & 2,334 \\
\hline \multicolumn{1}{c}{ Jumlah } & $\mathbf{9 , 6 6 6}$ & $\mathbf{2 0 , 6 6 6}$ & $\mathbf{1 1 , 0 0 0}$ \\
\hline
\end{tabular}

Sumber: Data Primer Terolah 2014

Berdasarkan Tabel 1,dapat dilihat pada saat pra test nilai aspek pengetahuan responden sebesar 9,666 (kurang tahu). Berdasarkan data hasil kuesioner pratest terlihat bahwa petani rata-rata belum mengetahui tentang manfaat kotoran ayam, pengertian bokashi, manfaat pupuk bokshi maupun cara membuatnya. Rata-rata petani belum mengetahui manfaat kotoran ayam, mereka hanya membuang saja kotoran ayamnya ke sungai atau diberikan ke kolam sebagai pakan ikan bagi yang memiliki ikan. Bahkan petani yang tidak mengkandangkan ayamnya membiarkan kotoran ayam mencemari lingkungan sekitarnya. Mereka belum mengetahui bahwa dengan mengkandangkan ayamnya maka kotoran ayam dapat dikumpulkan dan dapat dimanfaatkan sebagai bahan pembuatan pupuk bokashi yang bermanfaat bagi tanah.

Setelah dilaksanakannya penyuluhan terjadi peningkatan aspek pengetahuan petani dengan jumlah 20,66 yang menunjukkan bahwa respons petani tinggi dalam menerima pengetahuan. Dengan demikian tingkat pengetahuan petani meningkat sebesar 11 atau dari kategori respons tinggi.Peningkatan respons aspek pengetahuan petanidikarenakan petani sangat merespons materi yang disampaikan. Hal ini ditunjukkan dengan keseriusan petani dalam mendengarkan materi yang disampaikan karena materi yang disampaikan sangat sesuai dengan kebutuhan petani. Hal ini sesuai dengan pendapat Anik R (2012) bahwa materi penyuluhan pertanian yang akan disampaikan penyuluh kepada pelaku utama maupun pelaku usaha harus memberikan dampak yang positif dan didalam memilih materi penyuluhan haruslah benar-benar sesuai dengan kebutuhan sasaran.

\section{Aspek sikap}

Hasil analisis pra test dan post test pada aspek sikap responden menunjukan data seperti terlihat pada Tabel 2 
Tabel 2. Hasil Penilaian pada Aspek Sikap

\begin{tabular}{lccc}
\hline \multicolumn{1}{c}{ Variabel pertanyaan } & \multicolumn{2}{c}{ Nilai rata - rata } & \multirow{2}{*}{ Selisih } \\
& Pra test & Post test & \\
\hline Manfaat kotoran ayam & 3,733 & 5,0 & 1,267 \\
Manfaat bokashi & 3,267 & 5,0 & 1,733 \\
Penggunaan pupuk bokashi & 2,700 & 3,6 & 0,900 \\
Pembuatan bokashi & 1,400 & 3,6 & 2,200 \\
Penyuluhan bokashi & 5,000 & 5,0 & 0000 \\
\hline Jumlah & $\mathbf{1 6 , 1}$ & $\mathbf{2 2 , 2}$ & $\mathbf{6 , 1}$ \\
\hline
\end{tabular}

Sumber: Data Primer Terolah 2014

Dari Tabel 2 terlihat bahwa sebelum penyuluhan rata-rata responden masih kurang setuju dalam memanfaatkan kotoran ayam dan kurang setuju untuk membuat sendiri pupuk bokashi, dan setelah diberikan penyuluhan semua responden menjadi setuju untuk memanfaatkan kotoran ayam untuk dibuat pupuk bokashi. Sebagian besar petani juga setuju untuk membuat sendiri pupuk bokashi dan setuju untuk memupuk tanamannya menggunakan pupuk organik. Semua responden setuju untuk mengikuti penyuluhan karena sangat bermanfaat. Pengukuran aspek sikap menunjukan bahwa responden setuju terhadap materi yang disampaikan, hal ini ditunjukan dari sikap petani / peternak dengan antusias aktif mengikuti jalannya penyuluhan yang diberikan. Menurut Suriatna (1987), selain waktu, keaktifan responden dalam mengikuti kegiatan penyuluhan juga berpengaruh pada perubahan sikap dalam menerima inovasi.

\section{Aspek keterampilan}

Hasil analisis pra test dan post test pada aspek keterampilan responden menunjukan data seperti terlihat pada Tabel 3.

Tabel 3. Hasil Penilaian pada Aspek Keterampilan

\begin{tabular}{lccc}
\hline \hline \multirow{2}{*}{ Variabel pertanyaan } & \multicolumn{2}{c}{ Nilai rata - rata } & \multirow{2}{*}{ Selisih } \\
\cline { 2 - 3 } & Pra test & Post test & \\
\hline Terampil menyiapkan bahan pembuatan bokashi & 1,667 & 4,733 & 3,066 \\
Terampil menimbang bahan pembuatan bokashi & 1,133 & 3,533 & 2,400 \\
Terampil membuat bokashi & 1,200 & 3,533 & 2,333 \\
Ciri-ciri bokaashi yang sudah jadi & 1,267 & 4,400 & 3,133 \\
\hline \multicolumn{1}{c}{ Jumlah } & $\mathbf{5 , 2 6 7}$ & $\mathbf{1 6 , 1 9 9}$ & $\mathbf{1 0 , 9 3 2}$ \\
\hline
\end{tabular}

Sumber: Data Primer Terolah 2014

Berdasarkan Tabel 3, nilai pra test pada aspek keterampilan menunjukkan angka 5,267 dikategorikan kurang terampil, sedangkan hasil post test setelah dilakukan kegiatan penyuluhan menunjukan angka 16,199. Respons meningkat menjadi terampil dengan selisih kenaikan 10,932.
Respons petani terhadap pemanfaatan feses ayam sebagai pupuk bokashi meningkat hal ini ditunjukan dari hasil pra test dan post test yang telah dilakukan. Petani sudah mulai mengunakan pupuk bokashi bagi kelangsungan tanaman mereka.Menurut Kartasapoetra (1988) bahwa pengukuran 
aspek keterampilan dipengaruhi beberapa faktor berikut: a. Metode penyuluhan. Metode penyuluhandengan pendekatan kelompok biasanya lebih efektif dan lebih bermanfaat apabila dilakukan terhadap kelompok tani,dimana petani diajak dan dibimbing serta diarahkan untuk melakukan kegiatan yang lebih preduktif atas dasar kerjasama. b. Teknik penyuluhan. Teknik penyuluhan yang digunakan adalah ceramah, diskusi dan demonstrasi cara. Dengan demikian petani ikut berpartisipasi akan lebih memahami materi yang disampaikan.

Faktor - Faktor yang Mempengaruhi Respons Petani Terhadap Pemanfaatan Feses Ayam Sebagai Pupuk Bokashi

\section{Faktor-faktor yang mempengaruhi respons petani}

Analisis data dijelaskan berdasarkan

hasil output analisis SPSS menggunakan analisis regresi linier barganda. Hasil analisis regresi linier berganda dengan variabel respons sebagai variabel terikat (dipendent) dan pendidikan petani, umur petani, pengalaman beternak serta jumlah kepemilikan ternak sebagai variabel bebas (independent). Analisis regresi linier berganda menunjukan persamaan sebagai berikut:

$$
\begin{gathered}
\mathrm{Y}=68,816+2,384 \mathrm{X}_{1}+(-376) \mathrm{X}_{2}+0,339 \mathrm{X}_{3} \\
+0.005 \mathrm{X}_{4}+\mathrm{e}
\end{gathered}
$$

Keterangan:
$\mathrm{Y}=$ respons petani

$\mathrm{a}=$ konstanta

$\mathrm{b}_{1}, \mathrm{~b}_{2}, \mathrm{~b}_{3}, \mathrm{~b}_{4}=$ koefisien regresi

$\mathrm{X}_{1}=$ pendidikan

$X_{2}=$ umur

$\mathrm{X}_{3}=$ pengalaman

$\mathrm{X}_{4}=$ jumlah kepemilikan ternak

$\mathrm{e}=$ faktor lain diluar persamaan

\section{a. Analisis determinasi linier ganda $\left(\mathbf{R}^{2}\right)$}

Analisis ini digunakan untuk mengetahui persentase sumbangan pengaruh variabel independen secara serentak terhadap variabel dipenden. Koefisien ini menunjukkan seberapa besar persentase varisai variabel independen yang digunakan dalam model mampu menjelaskan variasi variabel dependen. $\mathrm{R}^{2}$ sama dengan 0 , maka tidak ada sedikitpun variasi variabel dependen. Sebaliknya nilai $\mathrm{R}^{2}$ sama dengan 1, maka persentase sumbangan pengaruh yang diberikan variabel independen terhadap variabel dependen adalah sempurna atau variasi variabel independen yang digunakan dalam model menjelaskan $100 \%$ variasi variabel dependen.

Dari hasil analisis regresi, dilihat pada outputmodel summary disajikan sebagai berikut:

Tabel 4. Hasil Analisis Uji Model

\begin{tabular}{lcccr}
\hline \hline Model & $\mathrm{R}$ & $\begin{array}{c}\text { Koefisien } \\
\text { daterminan }\end{array}$ & $\begin{array}{c}\text { Koefisien determinan } \\
\text { terkoreksi }\end{array}$ & Kesalahan baku \\
\hline 1 & $0,797(\mathrm{a})$ & 0,635 & 0,577 & 4,194 \\
\hline Keterangan: & a. & $\begin{array}{l}\text { Prediktor: (konstan), jumlah kepemilikan ternak, umur, pengalaman } \\
\text { beternak, pendidikan }\end{array}$ \\
& b. & Variabel terikat: respon
\end{tabular}


Berdasarkan Tabel 4 diperoleh angka koefisien determinan terkoreksi sebesar 0,577 atau $57,7 \%$. Hal ini menunjukkan bahwa variabel independen (umur, pendidikan, pengalaman dan jumlah kepemilikan ternak) dapat menjelaskan variabel dependen (respons petani) sebesar $57,75 \%$, sedangkan sisanya dipengaruhi oleh variabel lain diluar model.

\section{b. Uji F statistik}

Uji ini digunakan untuk mengetahui apakah variabel independen secara bersama-sama berpengaruh secara signifikan terhadap variabel dependen. Dari hasil output analisis regresi dapat diketahui nilai F seperti pada Tabel 5 berikut ini.

Tabel 5. Hasil Analisis Uji F

\begin{tabular}{|c|c|c|c|c|c|c|}
\hline Model & $\begin{array}{l}\text { Sumber } \\
\text { keragaman }\end{array}$ & $\begin{array}{l}\text { Jumlah } \\
\text { kuadrat }\end{array}$ & $\begin{array}{c}\text { Derajat } \\
\text { bebas }\end{array}$ & $\begin{array}{l}\text { Kudrat } \\
\text { tengah }\end{array}$ & F hitung & Sig. \\
\hline \multirow[t]{3}{*}{1} & Regresi & 766,191 & 4 & 191,548 & 10,891 & $0,000(\mathrm{a})$ \\
\hline & Galat & 439,676 & 25 & 17,587 & & \\
\hline & Jumlah & 1205,867 & 29 & & & \\
\hline
\end{tabular}

Keterangan: $\quad$ a. $\quad$ Prediktor: (konstan), jumlah kepemilikan ternak, umur, pengalaman beternak, pendidikan

b. Variabel terikat: respon

Berdasarkan hasil analisis uji F kepemilikan ternak secara bersama-sama diperoleh nilai $\mathrm{F}$ hitung sebesar 10,891. berpengaruh terhadap respons petani.

Nilai $F$ tabel sebesar 2,75871. Karena F hitung > F tabel $(10,891>2,75871)$, maka Ho ditolak, artinya ada pengaruh sangat

\section{c. Uji t statistik}

Uji ini digunakan untuk mengetahui signifikan antara umur, pendidikan, apakah dalam model regresi variabel pengalaman beternak dan jumlah independen secara parsial berpengaruh kepemilikan ternak secara bersama-sama signifikan terhadap variabel dependen. Dari terhadap respons petani. Jadi dapat hasil analisis regresi output dapat disajikan disimpulkan bahwa umur, pendidikan, pada tabel 6. pengalaman beternak dan jumlah

Tabel 6. Hasil Analisis Uji t

\begin{tabular}{llrrrrr}
\hline \hline \multirow{2}{*}{ Model } & & \multicolumn{2}{c}{$\begin{array}{c}\text { Unstandardized } \\
\text { Coefficients }\end{array}$} & $\begin{array}{c}\text { Standardized } \\
\text { Coefficients }\end{array}$ & \multirow{2}{*}{$t$} & \multirow{2}{*}{ Sig. } \\
\cline { 3 - 5 } & & \multicolumn{1}{c}{$B$} & Std. Error & Beta & & \\
\hline 1 & (konstan) & 68,816 & 5,633 & & 12,216 & 0,000 \\
& Pendidikan & 2,384 & 1,439 & 0,285 & 1,657 & 0,110 \\
& Umur & $-0,376$ & 0,103 & $-0,589$ & $-3,650$ & 0,001 \\
& pengalaman beternak & 0,339 & 0,150 & 0,294 & 2,267 & 0,032 \\
& jlh kepemilikan & 0,005 & 0,003 & 0,196 & 1,446 & 0,161 \\
\hline & ternak & &
\end{tabular}

Keterangan: Variabel terikat: respon 
Berdasarkan hasil analisis $\mathrm{Uji} \mathrm{t}$ diperoleh hasil analisis dari uji $\mathrm{t}$ dari masing - masing variabel adalah sebagai berikut:

\section{1) Variabel pendidikan}

Berdasarkan hasil $t$ hitung, pendidikan tidak berpengaruh signifikan terhadap respons $(\mathrm{P}>0,05)$ artinya tidak ada pengaruh nyata pendidikan petani terhadap respons petani. Hal ini dikarenakan rata-rata responden memiliki tingkat pendidikan yang sama yakni berpendidikan SD, akan tetapi semua responden telah mengenyam pendidikan SD yang artinya semuanya sudah dapat membaca dan menulis sehingga memungkinkan dapat belajar dengan baik. Hal ini sesuai dengan pendapat Mardikanto (2009) yang menyatakan bahwa penyuluhan sebagai proses pendidikan untuk penyebarluasan informasi yang dapat merangsang terjadinya proses perubahan perilaku. Pendidikan akan memberikan wawasan berpikir lebih luas, lebih kritis dan cepat tanggap dan mudah menerima informasi.

\section{2) Variabel umur}

Berdasarkan hasil $t$ hitung umur berpengaruh sangat signifikan $(\mathrm{P}<0,01)$ dan berpengaruh secara negatif. Besarnya koefisien regresi dari variabel umur adalah negatif 0,376 artinya bahwa jika umur petani naik $1 \%$ maka respons akan berkurang sebesar 0,376\%. Hal ini ada kecenderungan semakin tinggi umur petani maka semakin rendah respons petani terhadap pemanfaatan feses ayam sebagai pupuk bokashi. Hal ini sesuai dengan pendapat Mardikanto (2009) yang menyatakan bahwa semakin tua umur biasanya semakin lamban mengadopsi inovasi dan cenderung hanya melaksanakan kegiatan-kegiatan yang sudah biasa diterapkan oleh warga masyarakat setempat.

\section{3) Variabel pengalaman beternak Berdasarkan hasil $t$ hitung} pengalaman beternak berpengaruh signifikan $(\mathrm{P}<0,05)$ terhadap respons petani. Besarnya koefisien regresi dari variabel pengalaman beternak adalah positif 0,339; artinya bahwa jika pengalaman beternak naik $1 \%$ maka respons akan bertambah sebesar 0,339\%. Hal ini ada kecenderungan semakin tinggi pengalaman petani maka semakin tinggi pula respons petani terhadap pemanfaatan feses ayam sebagai pupuk bokashi. Sesuai dengan pendapat Rukka dkk (2006), yang mengemukakan bahwa semakin lama pengalaman berusaha tani maka tingkat respons terhadap suatu teknologi akan semakin tinggi.

\section{4) Variabel jumlah kepemilikan ternak}

Berdasarkan hasil t hitung jumlah kepemilikan ternak tidakberpengaruh signifikan $(\mathrm{P}>0,05)$ terhadap respons petani. Artinya jumlah kepemilikan ternak tidak berpengaruh terhadap respons petani. Hal ini menunjukkan bahwa jumlah kepemilikan ternak di Desa Sinduagung rata-rata sama karena mereka tidak tau berapa jumlah ayam yang dapat dipelihara untuk memberikan keuntungan yang maksimal. Hal ini berbeda pendapat dengan Mardikanto (1993) yang menyatakan bahwa peternak yang memiliki ternak yang banyak biasanya lebih cepat dalam merespons teknologi/inovasi karena kemampuan ekonominya juga lebih tinggi, selain itu jumlah ternak akan memberikan hasil yang lebih banyak sehingga petani peternak akan semakin merespons teknologi inovasi yang mampu mengelola 
hasil usaha ternaknya agar dapat meningkatkan nilai jual dan pendapatannya.

\section{KESIMPULAN DAN SARAN \\ Kesimpulan}

Dari hasil penelitian di Desa Sinduagung Kecamatan Selomerto Kabupaten Wonosobo maka dapat disimpulkan sebagai berikut:

1. Respons petani terhadap pemanfaatan feses ayam sebagai pupuk bokashi mengalami peningkatan pada aspek pengetahuan dengan nilai 11 dari kategori tidak tahu menjadi tahu, aspek sikap 6,1 dari kurang setuju menjadi setuju, aspek keterampilan 10,322 dari tidak terampil menjadi terampil.

2. Hasil anilisis linier berganda menuunjukkan bahwa umur berpengaruh sangat nyata dan pengalaman beternak berpengaruh nyata terhadap respons petani dalam memanfaatkan feses ayam sebagai bokashi sedangkan pendidikan dan jumlah kepemilikan ternak tidak berpengaruh nyata terhadap respons petani dalam memanfaatkan feses ayam sebagai pupuk bokashi

\section{Saran}

1. Perlu ada monitoring sebagai tindak lanjut dari respons petani dalam memanfaatkan feses ayam sebagai pupuk bokashi yang dapat diterapkan dalam kehidupan sehari-hari oleh masyarakat desa setempat.

2. Perlunya anggota kelompok untuk menambah jumlah anggota usia muda sehingga keberadaan kelompok terus berkelanjutan. Selain itu pendidikan petani perlu ditingkatkan yaitu dengan memberikan penyuluhan yang sesuai dengan kebutuhan petani.

\section{DAFTAR PUSTAKA}

Anik, R. 2012. Menyusun Materi Penyuluhan Pertanian. http://anikrachmawati.blogspot.com/2012/12/ menyusun-materi-penyuluhanpertanian.3318.html. Diakses pada 4 Juni 2014.

Arikunto, S. 2002. Prosedur Penelitian Suatu Pendekatan Praktek. Jakarta: Rineka Cipta.

Hendry. 2010. Populasi dan Sampel. $\mathrm{http//terionline.wordpress.com./}$ 2010/populasi-dan-sampel/. Diakses pada 6 Maret 2014

Ibrahim, J. T, A. Sudiyono, dan Harpowo. 2003. Komunikasi dan Penyuluhan

Kartasapoetra. 1988. Metodologi Penelitian Sosial dan Pendidikan Teori Aplikasi. Jakarta: Bumi Aksara.

Komaruddin. 1987. Kamus Riset. Bandung: Angkasa.

Lingga, P. 1995. Petunjuk Penggunaan Pupuk. Jakarta: Penebar Swadaya.

Mardikanto, T. 1993. Penyuluhan Pembangunan Pertanian. Surakarta: Sebelas Maret University Press.

Mardikanto, T. 1999. Petunjuk Penyuluhan Pertanian. Surakarta: UNS. Press.

Mardikanto, T. 2009. Sistem Penyuluhan Pertanian. Surakarta: UNS Press.

Maspary. 2010. Peternakan Limbah Kotoran Unggas.

Padmowiharjo, S. 1999. Media Penyuluhan Pertanian. Jakarta: Universitas Terbuka. 
Padmowiharjo, S. 2000. Metode

Penyuluhan Pertanian. Jakarta:

Universitas Terbuka.

Pratama, Sandra. 2011. Pengertian Respon. http://pratamasandra.wordpress.com /2011/05/11/pengertian-respons diakses pada 6 Maret 2014.

Riduwan. 2010. Skala Pengukuran Variabel-Variabel Penelitian. Bandung: Alfabeta.

Rukka, H. dan Sunaryo Buhaerah. 2006. "Hubungan Karakteristik Petani dengan Respons Petani Terhadap Penggunaan Pupuk Organik pada Padi Sawah (Oryza sativa. L)." Jurnal Agrisistem. Vol 2. No 1. http://www.stpp-gowa.ac.id/ highlight/downloadjurnal/serisosek/ Vol-2\%20No\%201,\%202006/4.\%20 Hermaya\%20Rukka\%20cs.pdf. Diakses pada 4 Juni 2014.

Soehartono, I. 1998. Metode Penelitian Sosial. Bandung: Remaja Rosdakarya.

Suriatna. 1988. Beternak Sapi Potong. Yogyakarta: Kanisius. 